Serikkaliyeva A.E.

Chinese investment in the mining and metallurgical complex of Kazakhstan

Сериккалиева А.Е.

Қазақстанда тау-кен металмургиялық кешенінде Қытай инвестициямары

Сериккалиева А.Е.

Инвестиции Китая в горно-метаммургический комплекс Казахстана
The article shows the total investment activity in the mining industry of the Republic of Kazakhstan, and identifies the presence of the Chinese side in this financial activity. The mining and metallurgical sector is one of the most competitive and dynamically developing industries of Kazakhstan. "Investment for subsoil resources» is the formula of the Chinese investments, i.e. instead of the granted credits China requires the access to oil, gas, copper, gold and other deposits. Certainly, the Republic of Kazakhstan takes a special place in China's range of interest. It is associated with huge inner market of the region, high purchasing power in compare to other Central Asian regions, and, as a most important, with vast range of mineral resources, especially, of hydrocarbons.

Key words: Chinese investment, Kazakhstan, the mining and metallurgical complex, cooperation.

Мақаяада Қазақстан Республикасының тау-кен өнеркәсібіндегі жалпы инвестициялық белсенділігін көрсетеді, бұл іс-шараларды қаржыландыруға Қытайдың қатысуы анықталады. Тау-кен және метамлургия секторы Қазақстандағы ең бәсекеге қабілетті және серпінді салаларының бірі болып табылады. Қытайдың Қазақстандағы инвестициялық саясаты «Инвестиция салу арқылы табиғи ресурстармен пайдалану» формуласын ұстанады, берілген несиелер орнына Қытай мұнай, газ, мыс, алтын және басқа да пайдалы қазбаларға қол жеткізуге ұмтылады. Әрине, Қазақстан Республикасы Қытай мүдлелерінде ерекше орын алады. Бұл аймақтағы ірі ішкі нарықтың және пайдалы қазбалардың, соның ішінде көмірсутектердің барына байланысты және де Орталық Азияның басқа өңірлерімен салыстырғанда жоғары сатып алу қабілетінің арқасында.

Түйін сөздер: Қытай инвестициялары, Қазақстан, тау-кен және метаммургия кешені, ынтымақтастық.

В статье показана общая инвестиционная активность в горнодобывающей промышленности Республики Казахстан, определено присутствие китайской стороны в финансировании данной деятельности. Горно-металмургический сектор является оАной из наиболее конкурентоспособных и динамично развивающихся отраслей промышленности Казахстана. «Инвестиции в обмен на недропользование» данной формулы придерживается китайская инвестиционная политика, т.е. вместо выданных кредитов Китай добивается Аоступа к нефти, газу, меди, золоту и другим полезным ископаемым. Конечно, Республика Казахстан занимает особое место в интересах Китая. Это связано с большим внутренним рынком региона, высокой покупательской способностью по сравнению с Аругими регионами Центральной Азии, и, самое главное, с огромным диапазоном полезных ископаемых, в частности, углеводородов.

Кмючевые слова: китайские инвестиции, Казахстан, горнометалмургический комплекс, сотрудничество. 


\section{CHINESE INVESTMENT IN THE MINING AND METALLURGICAL COMPLEX OF KAZAKHSTAN}

Kazakhstan is one of the world's best-endowed states, possessing world-class deposits of minerals and raw materials. Out of 105 elements of Mendeleev's Table, 99 elements have been discovered in subsoil of Kazakhstan, 70 elements have been explored and over 60 elements have been involved in production. The mining and metallurgical sector is one of the most competitive and dynamically developing industries of Kazakhstan. Almost 164.5 thousand people of key professions are engaged therein. Kazakhstan holds $30 \%$ of world resources of chromium ore, $25 \%$ of manganese ore and $10 \%$ of iron ore. Copper, lead and zinc resources constitute $10 \%$ and $13 \%$ of the world reserves, respectively. The total geological resources and predicted resources of coals in Kazakhstan are estimated to be 150 billion tons. The Republic is on the $13^{\text {th }}$ place in the world among 70 mining states according to the level of production of solid mineral resources. Comparing to 2013, in 2014 total export volume increased by $2.6 \%$ and passed 3.6 billion KZT. The sector provides $11.4 \%$ of Kazakhstan's GDP. MMC (Mining and Metallurgical Complex) is the base of the economic industrialization of the country. This industry branch employing more than 190000 people, effectively use its export potential. [1]

At the beginning of 2014, the Industrialization Map of Kazakhstan included 61 mining and smelting industry projects, representing investment US\$10.0 billion. In 2011, eleven projects brought the economy US \$ 351.9 million and 2,700 new jobs. [2]

After Kazakhstan got independence in 1991, it became the focus of interest of some world-powered countries one of which was China. "Investment for subsoil resources" is the formula of the Chinese investment, i.e. instead of the granted credits China requires the access to oil, gas, copper, gold and other deposits. Certainly, Kazakhstan takes a special place in China's range of interest. It is associated with huge inner market of the region, high purchasing power in compare to the other Central Asian regions, and most importantly, with vast range of mineral resources, especially, of hydrocarbons. [3] The first impulse for starting of the bilateral energy relations was set in May, 1997 by signing of the Intergovernmental Agreement concerning oil and gas sectors, and the General Agreement between the Ministry of Energy and Mineral Recourses of Kazakhstan and Chinese National Petroleum Corporation (CNPC) in sphere of oil and gas exploration and construction of the Kazakhstan-Chinese 
petroleum pipeline. According to statistics of the Customs Control of Kazakhstan, China became the third largest trading partner of the country in 2008. In 2009 it came up to the second place for trading volumes as a largest importer $(12 \%$ of the total imports of Kazakhstan) and exporter (13.6\% of the total exports). Complied with the reports of the Customer Clearance of Kazakhstan, export to China specifies as a raw orientated. So, in 2009, oil and other main mineral recourses exported to China received $52.9 \%$ of total exports, particularly, cure oil $-38.7 \%$, copper and copper alloys $-11.4 \%$, natural uranium - 9,7\%, iron stones and concentrates - 7,6\%. Imported Chinese goods are as follows: steel tubes (26\% of total imports) and equipment, presented by bulldozers, blade-scrapers, diggers, scrappers and other technique $(2,0 \%$ of total imports). This data shows that imported Chinese goods have a lot of varieties and some of these goods are used in the production of the investment activity of Chinese companies in Kazakhstan. [4] China gave a 2, 7 billion dollars credit to Kazakh Company "Kazakhmys" in 2010 and 1, 5 billion dollars in 2011 for exploration of the "Aktogay" mining pit. [5]

\section{Share of MMC in whole industrial sector of Kazakhstan}
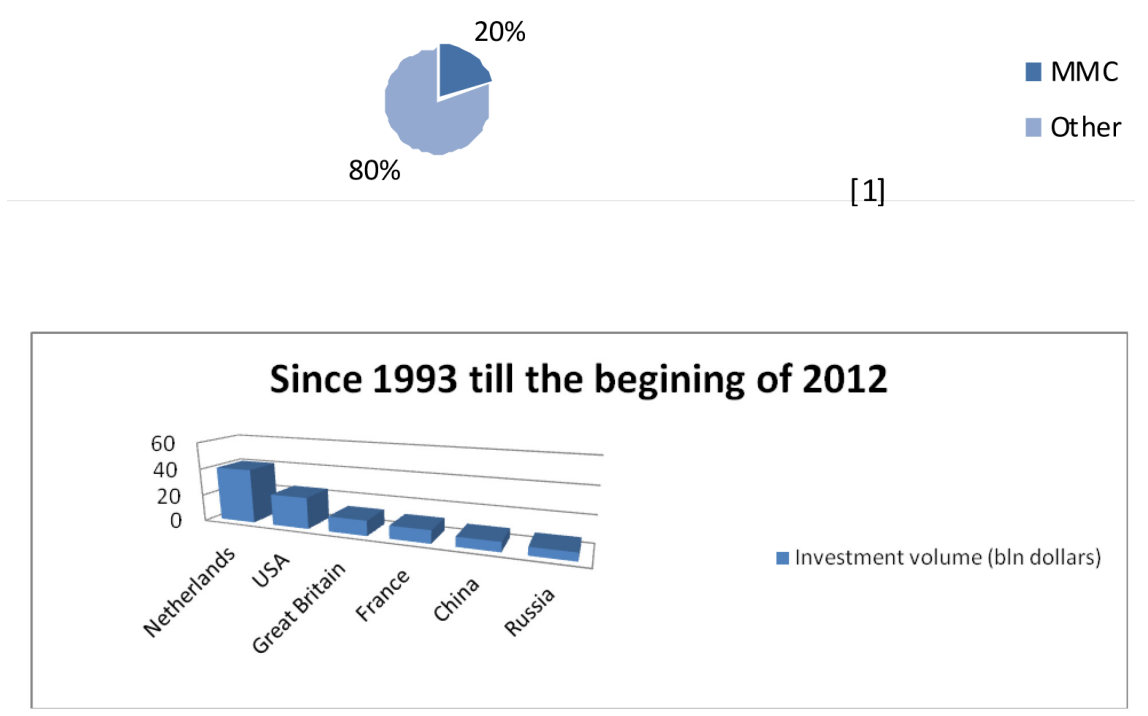

It should be noted that the amount of Chinese direct investments to the economy of Kazakhstan was not huge until the 2000th. In 1993- 2012 period, Kazakhstan received only 7,1 billion dollars investment from China. Among the biggest investors China took only the sixth place, after Netherlands (40, 4 billion dollars), the USA (23, 35 billion dollars), the Great Britain (11, 26 billion dollars) and France (9, 59 billion dollars), but moved ahead of Russia (5, 95 billion dollars). [6] However, some analytics points out that China shows the great dynamic of the direct investments in the Common Free Market Zone countries that fully reflect the expansion of the Chinese companies in recent years. Even six years ago, according to the investment volume in Kazakhstan, China could be scaled with India, Russia and Belarus, but now China is considerably superior to them. It was achieved because of the large-scale of presence of Chinese companies in Kazakhstan's market. High amount of Chinese direct investments in Kazakhstan is an important element for the realization of the idea of New Silk Road Economic Belt. At present, the main Chinese investment projects are related with fuel complex. [7]

Nowadays the Government of Kazakhstan has been trying to get more investors onboard, and that is why "Complex work plan for getting more international and domestics investments into economy of Kazakhstan" was adopted, which stipulate tax remission for those investors whose investment amount will be up to 20 million dollars. As ViceMinister of Economics and Budget Planning of Kazakhstan Marat Kusainov said that these benefits will be given only to the large investing companies for creating of the "anchored" projects. [8] Growth, shows a study by Business Monitor published 
in September, 2014, will be led by the coal, gold and copper sectors, which together account for the majority of the value of the Central Asian nation's mining industry, expected to reach close to $\$ 30$ billion by 2017. [9] With an aim to develop economic welfare and increase the wealth of their citizens, Kazakhstan President Nursultan Nazarbayev and Chinese President Xi Jinping during their meeting in Shanghai on May 25th, 2014 signed a couple of agreements on economic relations between two states. These documents foresee multibillion investments. Among the reached agreements was Memorandum of cooperation in petroleum and ore mining sectors between Kazakh found "Samruk-Kazyna" and Chinese CITIC Company. Also the prospects of realization of joint projects in IT, uranium, coil mining sectors were made. 60 new production facilities in the amount of 2.5 bn dollars were commissioned in the first five-year plan of industrialization in $\mathrm{Ka}$ zakhstan MMC. More than 16 thousand permanent jobs have been created, said First Deputy Prime Minister Bakhytzhan Sagintayev at the 7th International Congress "Astana Mining \& Metallurgy" AMM 2016. [10]

To conclude, Kazakhstan is the state of the high interest of international investors, and especially from China, which is one of the wealthiest neighbors, annually investing million dollars in Kazakh industrial sector. According to the report of Chinese Minister of Commerce, Kazakhstan takes the third place after Hong Kong and the USA in amount of direct investments of China. [11] As for Kazakhstan, the Vice Minister of Health and Social Development of Kazakhstan Daulet Argandykov has informed that the largest number of guest workers coming to Kazakhstan is from China. According to Argandykov, 31\% (9,6 thousand people) of foreign workers arrived from China, and 7, 4\% (about 2, 3 thousand people) of these workers are working in the mining sector.

\section{Литература}

1 О ГМК Казахстана // Портал Ассоциации Горнодобывающих и горно-металлургических предприятий Казахстана. AGMP.KZ/PAGE/VIEW/O GMK KAZAHSTANA?LANG=RU

2 The mining Industry in Kazakhstan // http://www.miningworld.kz/en/press-centre/news/66-17-01-2014mining

3 Известия. - 2011. - 25 октября.

4 Проблемы и перспективы торгово-экономического сотрудничества между Казахстаном и KHР // http://articlekz.com/ $\operatorname{article} / 8023$

5 Итоги внешней торговли Республики Беларусь за январь - декабрь 2009 года. // Государственный Таможенный комитет Республики Беларусь. http://gtk.gov.by/ru/stats/itogi_statistiki_2009/statistika_janv_dec_2009

6 Иконников А. Барахольный блюз // ЦентрАзия. - 2010. - №2.

7 Казахстан привлекает китайских инвесторов // Деловой портал. http://dknews.kz/kazahstan-privlekaet-kitajskih-investorov/

8 Входной билет в «налоговый рай» - \$20 млн // http://forbes.kz/finances/investment/v_kazahstane_krupnyih_investorov_ osvobodyat_ot nalogov na 10 let

9 The mining Industry in Kazakhstan // http://www.miningworld.kz/en/press-centre/news/66-17-01-2014mining

10 Инвестиции Китая в Казахстане идут в основном в энергетику // http://rus.azattyq.org/content/kazakhstan-chinaoil/25391701.html

11 Казахстан - третий в мире по объему китайских инвестиций, - ТхеТелеграпх // http:/www.kursiv.kz/news/details/ finansy/kazakhstan_tretiy_v_mire_po_obemu_kitayskikh_investitsiy the telegraph/

12 Наибольшее количество иностранных рабочих приезжает в Казахстан из Китая - вице-министр // http://strategy2050. $\mathrm{kz} / \mathrm{ru} / \mathrm{news} / 18196$

\section{References}

1 O GMK Kazahstana // Portal Associacii Gornodobyvajushhih i gorno-metallurgicheskih predprijatij Kazahstana. AGMP. KZ/PAGE/VIEW/O_GMK_KAZAHSTANA?LANG=RU

2 The mining Industry in Kazakhstan // http://www.miningworld.kz/en/press-centre/news/66-17-01-2014mining

3 Izvestija - $2011-25$ oktjabrja.

4 Problemy i perspektivy torgovo-jekonomicheskogo sotrudnichestva mezhdu Kazahstanom i KNR // http://articlekz.com/article/8023

5 Itogi vneshnej torgovli Respubliki Belarus' za janvar' - dekabr' 2009 goda. // Gosudarstvennyj Tamozhennyj komitet Respubliki Belarus'. http://gtk.gov.by/ru/stats/itogi statistiki 2009/statistika janv dec 2009

6 Ikonnikov A. Barahol'nyj bljuz // CentrÄzija. - 2010. - №2.

7 Kazahstan privlekaet kitajskih investorov // Delovoj portal. http://dknews.kz/kazahstan-privlekaet-kitajskih-investorov/

8 Vhodnoj bilet $\mathrm{v}$ «nalogovyj raj» - $\$ 20 \mathrm{mln} / / \mathrm{http} / / /$ forbes.kz/finances/investment/v_kazahstane_krupnyih_investorov_osvobodyat ot nalogov na 10 let

$9^{-}$The mining Industry in Kazakhtan // http://www.miningworld.kz;

10 Investicii Kitaja v Kazahstane idut v osnovnom v jenergetiku // http://rus.azattyq.org/content/kazakhstan-china-oil/25391701.html

11 Kazahstan - tretij v mire po ob\#emu kitajskih investicij, - TheTelegraph // http://www.kursiv.kz/news/details/finansy/kazakhstan_tretiy_v_mire_po_obemu_kitayskikh_investitsiy_the_telegraph/

12 Naibol'shee kolichestvo inostrannyh rabochih priezzhaet v Kazahstan iz Kitaja - vice-ministr // http://strategy2050.kz/ru/news/18196 